has now been published (pp. 13; from the Centre, New Delhi, 1953). The Centre was set up on July 7, 1951, under an agreement with the United Nations Educational, Scientific and Cultural Organization, providing for technical assistance over three years. It is situated in the National Physical Laboratory of India, New Delhi, and is under the administrative control of Sir K. S. Krishnan, assisted by an advisory committee. All possible steps are being taken to obtain and hold copies of scientific periodicals required in India, particularly by the universities, scientific research organizations and government laboratories, and the Centre is now in a position to supply to any country a copy of an article published in any Indian scientific periodical. Other functions of the Centre are to prepare an index of periodicals available, to act as a national repository for reports of Indian scientific work, to deal with inquiries, and generally to act as a means of making the scientific work of India and the surrounding countries known and available to the rest of the world. Three scholarships were provided by Unesco during 1952 for training suitable candidates in special fields of study relating to the project. The information service has been organized and the translation service supplemented by a panel of translators on which twentythree persons are at present enrolled, and it is proposed to issue a monthly bibliographical bulletin giving the titles of scientific papers published in Indian and foreign periodicals and a list of translations available.

\section{Current Periodicals in the Science Library, London}

THE seventh edition of the "Hand List of Short, Titles of Current Periodicals in the Science Library" (pp. 388; L.ondon: H.M.S.O., 1953; 10s. net), which was first published in 1904, contains about 8,500 titles of periodicals now being received, compared with the 7,000 entries of the sixth edition (1950). The order of entries is that of the "World List of Scientific Periodicals", with the exception that periodicals which have distinctive titles commencing "Journal", "Bulletin", etc., follow journals, bulletins, reports, etc., of societies, institutions, etc., and do not appear in one alphabetical order. Thus, the "Journal of Allergy" is not placed between "Journal, Alabama Academy of Science" and "Journal, American Ceramic Society", but after "Journal, Yorkshire Agriculture Society". In all entries, the dates following the semi-colon are dates of publication; but the range of years covered by a single report, and the years covered by runs and any gaps in a series of volumes, are also indicated. There are no cross-references, but extra entries are made under alternative forms of the title; and although a periodical is entered only under its current title or titles, the heading shown is inclusive of its earlier titles. Shelf-marks are given at the end of the entries and should be quoted by all users of the list so as to expedite service.

\section{Finances of the United States National Science Foundation}

A FURTher inquiry by the National Science Foundation indicates that Federal agencies in the United States spent 1,839 million dollars on scientific research and development during the fiscal year 1952, the corresponding estimate for 1953 being 2,189 million dollars, and the president's budget of January 9 included 2,327 million dollars for the year 1954 . During each of these years funds administered by the Department of Defense amounted to 72 per cent of the total, compared with the $\mathbf{1 4}$ per cent for the Atomic Energy Commission and 4 per cent for both the National Advisory Committee for Aeronauties and the Federal Security Agency. During 1952, 307 million dollars was allotted for increase of existing research facilities or construction of new laboratories, 198 million dollars of this going to the Department of Defense and 60 million to the Atomic Energy Commission.

\section{University of Sheffield}

THe United Steel Companies, Ltd., have established a research fellowship in metallurgy in the University of Sheffield, tenable in the Department of Metallurgy, the object of which will be to advance metallurgical knowledge and not to train persons for research. Appointments to the fellowship will be made from time to time from among scientific workers who have already served their apprenticeship in research and have shown ability to conduct independent investigations. The field of study within which they will be expected to work will be ferrous metallurgy, but this does not exclude the appointment of researchers in refractory matters, knowledge of which is of great importance in ferrous metallurgy. The fellowship will be worth at least $£ 750$ for the first year, rising by annual increments of $£ 50$, and will be normally held for five years.

The following have been appointed lecturers in the University of Sheffield : K. H. Sutherland and E. P. Bernat (mechanical engineering); Dr. W. Eastwood and C. Osgerby (civil engineering); and F. G. WestOram (glass technology).

\section{Institute of Navigation: Officers for 1953-54}

THE following have been elected officers for 195354 of the Institute of Navigation : President, D. $\mathrm{H}$. Sadler, superintendent of H.M. Nautical Almanac Office; Vice-Presidents, Air Chief Marshal the Hon. Sir Ralph Cochrane, formerly Vice-Chief of the Air Staff, and Captain F. J. Wylie, R.N. (ret.), director of the Radio Advisory Service; Honorary Treasurer, Francis Chichester ; Chairman of the Technical Committee, Wing Commander E. W. Anderson ; Chairman of the Executive Committee, Captain G. C. Saul, deputy master of the Honourable Company of Master Mariners.

\section{Colonial Service : Recent Appointments}

THE following appointments have recently been made in the Colonial Service : R. B. Allnutt (assistant director of agriculture, Nigeria), deputy director of agriculture, Western Region, Nigeria; M. A. G. Hanschell (agricultural officer, Sierra Leone), development commissioner, St. Lucia; C. A. S. Hynam (agricultural officer, Trinidad), agricultural officer, British Honduras; A. Jefferiss (agricultural officer, Tanganyika), director of agriculture, Seychelles; E. A. Tai (senior agricultural officer, Jamaica), agronomist, Trinidad; E. H. Jaques (geologist, Federation of Malaya), principal geologist, Federation of Malaya; H. E. F. Savage (principal geologist, Federation of Malaya), deputy director, Geological Survey, Federation of Malaya; G. H. S. Wood (assistant conservator of forests, Uganda), senior scientific officer, forest botanist, North Borneo; E. Millington (senior agricultural survey officer, Gold Coast), principal agricultural survey officer, Gold Coast; V. I. Mulloon (senior agricultural assistant, 